\title{
The Value of Agroforestry Ecosystem Services \\ Provided in Rural Communities in the Eastern Amazon

$$
\text { (Tomé-Açu - PA, Brazil) }
$$

Gilmara Maureline Teles da Silva de Oliveira (Corresponding Author)

Socio-Environmental and Water Resources Institute of the Federal Rural University of the Amazon and Postgraduate Course of the Nucleus of High Amazonian Studies. CEP. 66077-830. Belém, Pará, Brazil. E-mail: gilmarateles.eng@gmail.com

\section{Antônio Cordeiro de Santana}

Socio-Environmental and Water Resources Institute of the Federal Rural University of the Amazon and Postgraduate Course of the Nucleus of High Amazonian Studies. CEP.

66077-830. Caixa Postal, 917. Belém, Pará, Brazil. E-mail: acsufra@gmail.com

Eder Silva de Oliveira

Environmental and Sanitary Engineering department, State University of Pará, CEP. 66095-015. Belém, Pará, Brazil. E-mail: ederso@uepa.br

\section{Rodrigo Jesus Silva}

Federal Rural University of the Amazon (UFRA), Tomé-Açu, PA, Brazil. CEP. 68680-000. E-mail: rodrigo.silva@ufra.edu.br

Washington Aleksander Savaris dos Santos

Department of Environmental Engineering of the State University of Pará. CEP. 66095-015. Belém, Pará, Brazil. E-mail: alex.uepa@gmail.com

Ádamo Lima de Santana

Corporate R\&D Headquarters, Fuji Electric, Tokyo, Japan. E-mail:

alwkynew@gmail.com

Vivian Christine Nascimento Costa 
Soil Science department, Institute of Agrarian Sciences, Federal Rural University of Amazon,

CEP. 66077-830. Belém, Pará, Brazil. E-mail: vivian.costa.1993@gmail.com

Received: July 10, 2020

doi:10.5296/jas.v8i4.17338
Accepted: August 10, 2020

Published: August 12, 2020

URL: https://doi.org/10.5296/jas.v8i4.17338

\begin{abstract}
The objective of this research is to estimate the socioeconomic and environmental value of ecosystem services produced by Agroforestry Systems of Tomé-Açu in society's perception. These systems, in addition to fruits, seeds, and nuts, provide other services that are perceived by society in the form of welfare, and are not yet sold on the market. For the analysis, the Integrated Method of Contingent Valuation was employed, which contemplates the economic, social and environmental dimensions. This approach relied in the equations modelling the Willingness to Pay for the conservation of Agroforestry Systems, and Willingness to Accept a compensation for not using these systems over other commercial production systems such as oil palm and soybean. The average value of ecosystem services in the Agroforestry Systems of Tomé-Açu in the population's perception was estimated at $\mathrm{R} \$ 5.011,19 \mathrm{ha}^{-1}$ for the Willingness to Pay and $\mathrm{R} \$ 7.367,24 \mathrm{ha}^{-1}$ for the Willingness to Accept. This indicates the importance given by the community to the benefits generated by the ecosystem services, in a magnitude higher than the market value of the Amazon rainforest and of the production systems. Therefore, the value of these services should also integrate the payment to compensate the producers that maintain these systems in the Amazon.
\end{abstract}

Keywords: agroforestry systems, amazon, conservation of biodiversity, valuation, natural asset

\title{
1. Introduction
}

Worldwide acquaintances, the Agroforestry Systems of Tomé-Açu, are referred as ASTAs, doing an allusion to the county name, are composed of crops of native or exotic woody, fruit, oil and medicinal tree species, among others, simultaneously and in the same environment (Barros et al., 2011). These systems in the county were applied by Japanese-Brazilian farmers as a result of the search of productive alternatives due to Fusarium invasion in the pepper plantations in 1957 and devastation from 1970 onwards, in addition to the prices fall in function of plantations expansion.

The perennial and annual crops at Tomé-Açu were implemented to enhance the use of areas before, after and during the cultivation of Black Pepper, which consists in the main culture. All of these cultures' combinations aiming the market, generated many AS at the county, with economic profitability and risk mitigation demonstrated in studies as Sanguino et al. (2007) and Varela and Santana (2009). 
The dynamics and diversity of these systems, with permanent and temporary cultures, produce wood, fruits, seeds, oils, medicinal essences and many Ecosystem Services as climate regulation, as greenhouse effect gases, nutrient cycling, control of pest and diseases, in addition of generate employment and income to the rural communities along the year.

In fact, these systems account for the ecosystem services produced by the natural assets of the ASTAs of rural properties in the municipality of Tomé-Açu (Barros et al., 2009; Santana et al., 2018). However, the interaction of fauna and flora in the ASTAs of rural properties generates a continuous flow of ecosystem services.

This flow of services is incorporated at society's through improvements in the welfare by simple functions that the ecosystems from ASTAs produce, which can be divided in four categories (MEA, 2003; Costanza et al., 1997; Wallace, 2007; Santana et al., 2016; Costanza et al., 2017): (I) provision service as food and fibers, wood, seeds, genetic resources, biochemical products, medicinal, pharmaceutics, ornamental and water; (II) environmental regulation service as the weather control, storms, winds, pollination, plagues and diseases, water and air purification and soil protection; (III) the cultural service as the cultural and social values, religious and spiritual, fauna and flora knowledge, landscapes values, recreation and tourism; and (IV) support service that defines the production of others services as the formation and retention of soil, photosynthesis, nutrient cycle, soil biological activity, water cycle and maintenance of habitat dynamics.

In this context, the value of these services can be incorporated into the rural properties value and should be compensated by the benefits they produce for the population and the environment, once they acknowledge their importance and declare their willingness to pay to continue enjoying these benefits or to receive them through substitution by other environmentally deficient production systems (Santana, 2017; Santana et al., 2018). Therefore, the question to be answered on this research is how much the population are willing to pay, besides the price of bare land, for ecosystem services of supply, regulation, culture and formation of soil structures, water courses, vegetation and biodiversity provided by ASTAs?

The hypothesis that arises from this question is that the economic value from these ecosystem services exceeds the average market price of land occupied with agriculture, livestock and forest in the county and surrounding region. To answer this question and test the formulated hypothesis, it were applied the Integrated Method of Contingent Valuation (IMCV) suggested by Santana (2015), for specify a simultaneous model with the equations of Willingness to Pay (WTP) by the ASTAs preservation and Willingness To Accept (WTA) by the ASTAs substitution for others productive systems and integrate the knowledge of neoclassic and ecologic economy in the definition of the model equations (Santana, 2014; Santana, 2015; Santana et al., 2017).

Hence, the research objective was to value the ecosystem services of the ASTAs in society's perception to internalize them to the market value of these systems in the region in a perspective of their conservation and maintenance of the welfare of local, regional and global society. 


\section{Theoretical Foundations}

In order to understand the nature of economic value, the instrument of neoclassical economic theory of the consumer is incorporated, where the individual with the limited budget makes several combinations of goods and services to maximize their utility function, which reflects the welfare (Marshall, 1982; Farber et al., 2002).

From this perspective, the total economic value of ecosystem services is based in the concept of Economic Surplus proposed by Marshall (1982), which is composed by the Producer Surplus, equivalent to the net revenue or profit (area above the supply line and below the market equilibrium price of a given good or service), and by the Consumer Surplus, given by the difference between the maximum value consumers are willing and able to pay for a good or service and the equilibrium market price.

Thus, the Economic Surplus is the maximum welfare that society can obtain from the production and consumption of goods and services (Marshall, 1982; Costanza et al., 1997; Santana, 2015). As ASTAs are in rural properties, the externalities produced by ecosystem services for the benefit of society can be valued by analyzing the costs and social benefits of these natural assets to maximizing the welfare produced.

In this sense, the analysis of social costs and benefits can be expressed in the value of use (utility) and non-use (social) of the natural assets (Liu et al. 2010; Santana, 2015; Santana, 2018). According to Bishop and Romano (1998), Adams et al. (2008), Carson (2012), Santana et al., (2015), Santana et al. (2016), Santana et al. (2017), the total economic value (TEV) of ecosystem services can be expressed as follows:

\section{TEV = Use Value (UV) + Non-use Value (NUV)}

The TEV from a natural resource consists in the sum of the UV and NUV. We further highlight that UV is subdivided into direct and indirect use values, where the former concerns the consumption or direct enjoyment of natural resources as a source of raw material, food and medicinal products; and the latter is defined by the externalities that the resource produces in the form of its functions within ecosystems, such as maintenance of biodiversity, preservation of waterways and nutrient cycling (Baral et al., 2008; Santana et al., 2015).

The NUV, in turn, incorporates the option and the existence values. The former refers to the possibility of attributing the value of direct and indirect uses as an option in the near future; where as the existence value simply refers to the existence of the resource in the form of benefits generated by ecosystem services not associated with use, that is, it is related to the concept of intrinsic value and departs from the utilitarian approach to economic value (Tôsto 2010; Santana et al, 2015; Santana et al., 2016; Santana et al., 2017).

In particular, the ASTAs locally developed in rural properties and with adaptations from the Japanese immigration have characteristics that transcend the instrumental and utilitarian value, also including intrinsic values such as the cultural identity of the municipality, the promotion of natural amenities and the conservation of biodiversity.

We see that, to value the ecosystem services of ASTAs requires an analysis of their 
environmental, social and economic aspects, in order to be able to guide public policies for sustainable development in the rural sector.

In this research, instead of using the use value and the non-use value to estimate the total economic value of the natural asset, which presents great difficulty in categorizing assets in people's perception, the IMCV works with another theoretical foundation. The IMCV model focuses on variables associated with economic, social and environmental dimensions to estimate the value of natural assets and, in turn, the opportunity cost of preservation or replacement with other economic activities (Santana et al., 2017).

The decision to preserve or to explore the natural assets is modeled by the structural equation of willingness to pay and willingness to accept, both representing the maximum value of the welfare generated by ecosystem goods and services of natural assets to people. These equations are theoretically interrelated, therefore, should be specified by a system of equations to avoid error in the model specification. The WTP and WTA equations constitute the IMCV, which must be estimated using the method of Seemingly Unrelated Regression. Thus, the model generates the maximum welfare, estimated by the socio-economic and environmental surplus of the consumer and producer goods and services generated by natural assets (Santana et al., 2017).

The market demands of consumers for ecosystem products and services offered by the natural assets of rural properties are specified in the IMCV using the WTP and WTA equations, as follows:

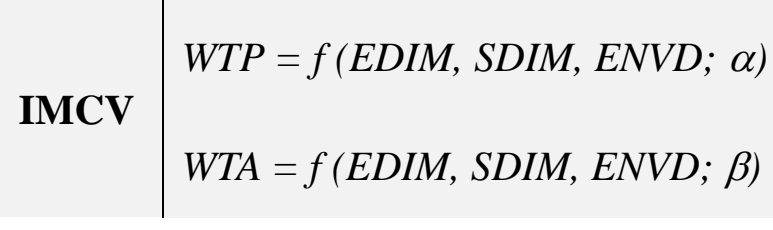

Where $\alpha$ and $\beta$ are the vectors of parameters to be estimated, EDIM is the economic dimension, SDIM is the social dimension, and ENVD is the environmental dimension.

\section{Method}

The research was carried out in the municipality of Tomé-Açu, located in the Northeast of Pará State, the Mesoregion of the Brazilian Eastern Amazon (IBGE, 2018). The data were obtained using a specific questionnaire applied to a representative sample of 382 interviewees from the population of 62.854 inhabitants of the municipality (IBGE, 2018).

The interviews were conducted from September to December of 2018. During the interview, it was sought to clarify the objective of the research, as well as the characteristics of the municipality's agroforestry system. In addition, images with many ASTA compositions were shown, to provide the necessary conditions for the interviewee to express his/her willingness to pay or receive a monetary value for the ecosystem services generated in these areas. The price ranges for land occupied with various agricultural systems, livestock and forests in the municipality and region were also presented.

The environmental dimension was constructed by applying factor analysis to 12 variables that 
shaped the environmental indicator, as provided in Santana (2018). In this way, the effect of environmental variables in the equations of willingness to pay and willingness to accept from the contingent evaluation can be obtained; then following the Integrated Method of Contingent Valuation (IMCV) proposed by Santana (2015), and avoiding multicollinearity problems due to the large number of qualitative variables in the equations, while integrating economic and ecological precepts.

The IMCV was used to value the ecosystem services provided by ASTAs, since they do not have a defined market price; for the adequacy of the methodology and contribution to other valuation studies, such as Santana and Khan (1992), Carson (2012), Groot et al. (2012), Santana (2014), Bentes et al. (2014), Santana et al. (2015), Rosa et al. (2016), Santana et al. (2016), Santana et al. (2017) and Begot (2018).

The model was composed of several variables expressed in the economic, social and environmental dimensions:

- Economic (EDIM), represented by the income variable and the dummy variable related to the differentiated values of WTPASTA and WTAASTA; which assumed zero for the average values and 1 for the values different from the average and which can influence significantly above the average;

- Social (SDIM), represented by the variables age, gender, time living in the location, education, main activity as source of income source and place of origin;

- Environmental (ENVD), represented by the environmental indicator and includes 12 variables related to the protection of watersheds and water quality, conservation and restoration of biodiversity, erosion control, recovery of degraded areas, use of pesticide, use of fertilizers, sustainable use of land in the Amazon, quality of life for the population, ASTAs as employment and income generation, scenic beauty and tourist attraction.

In the empirical model, the application of IMCV in the valuation of ecosystem services of ASTAs contemplated the equations of the Willingness to Pay a maximum amount for the maintenance of ASTAs areas in the municipality, called (WTPASTA), and the Willingness to Accept a minimum amount to give up the ASTAs areas in substitution for other production systems, called (WTAASTA). Thus, the equations were specified in a system of apparently unrelated equations, according to Santana (2015) and Santana et al (2016):

WTPAST $_{i}=\alpha_{10}+\alpha_{11}$ Age $_{i}+\alpha_{12}$ Gender $_{i}+\alpha_{13}$ Education $_{i}+\alpha_{14}$ Income $_{i}+\alpha_{15}$ Sfamily $_{i}+$ $\alpha_{16}$ Origin $_{i}+\alpha_{17}$ Environmental $_{i}+\alpha_{18}$ TQVNL $+\alpha_{19} A T V+\alpha_{110}$ VDWTP $_{i}+u_{i 1}$

WTAASTA $_{i}=\beta_{2 O}+\beta_{21}$ Age $_{i}+\beta_{22}$ Gender $_{i}+\beta_{23}$ Education $_{i}+\beta_{24}$ Income $_{i}+\beta_{25}$ Sfamily $_{i}+$ $\beta_{26}$ Origin $_{i}+\beta_{27}$ Environmental $_{i}+\beta_{28}$ TQVNL $+\beta_{29}$ ATV $+\beta_{210}$ VDWTA $_{i}+u_{i 2}$ 
Where: Gender - interviewee gender $i$ ( 0 for male and 1 for female); Education - level of education of interviewee $i$; Income - income of interviewee $i$ (in R $\$$ per month); Sfamily family size of interviewee $i$; Origin: place of origin of interviewee $i$; Environmental perception of the interviewee $i$ regarding the 12 variables related to ecosystem products and services provided by the ASTAs; TQVNL - how long interviewee $i$ lives in the municipality; ATV - Main activity as source of income; VDWTP - dummy variable related to the WTPASTA values (being 0 for the mean values and 1 for the different mean values and that can influence significantly above the mean); VDWTA - dummy variable related to the WTAASTA values (being 0 for the mean values and 1 for the different mean values and that can influence significantly above the mean); $\mathrm{u} 1, \mathrm{u} 2$ - random error terms; $\alpha_{1 \mathrm{j}, 2 \mathrm{j},}, \beta_{1 \mathrm{j}, 2 \mathrm{j}}(\mathrm{j}=1, \ldots, 10)$ - parameters of apparently unrelated equations, to be estimated by the method of Generalized Least Squares (GLS). With this method, the problem of heteroscedasticity is analyzed and equated, according to Santana et al. (2016).

\section{Results and Discussion}

Before presenting the analysis of the econometric model of contingent evaluation specified for the valuation of ASTAs, we will first introduce the synthesis of the socio-demographic and economic profile of the interviewees.

In general, the interviewed population agreed to participate in the survey and expressed the ability to answer questions about the benefits of agroforestry systems to the environment and welfare of the population, as well as to declare their preference regarding the conservation of ASTAs and/or replacement of these systems by other forms of land use.

The total was 398 interviews, greater than the minimum sample 382, which reduces the sampling error of $4.19 \%$ to $5 \%$. Of this total, $52.27 \%$ of participants were male and $45.73 \%$ female, with ages ranging from 15 to 85 years. With regard to the income of those interviewed, $81.16 \%$ earn up to three minimum wages and their main occupations as a source of income were: rural producers $(21.11 \%)$, self-employed $(19.10 \%)$, civil servants $(18.34 \%)$, company employees (6.78\%), extractivists (1.76\%) and entrepreneurs (1.76\%). The remaining practice varied activities.

Entering the analysis of the econometric model, the explanatory variables included in the WTPASTA and WTAASTA equations explained $55.8 \%$ and $69.2 \%$, of their variabilities, respectively.

The signs of the coefficients associated with the variables of the equations are in accordance with the theoretical assumptions and present statistical significance below 10\% (Table 1). The exception being for the parameters: variable family size, which was not significant in both equations; and the time lived in the municipality, in the WTAASTA equation. These results indicate that the model was correctly identified and the results could represent, in the population's perception, the real value of the ecosystem services produced by ASTAs. 
Table 1. Parameters of the WTPASTA and WTAASTA equations, Tomé-Açu, Pará

\begin{tabular}{ccccc}
\hline Variables & Coefficient & t-Statistics & Probability & $\begin{array}{c}\text { WTPASTA } \\
\text { Average }\end{array}$ \\
\hline Intercept & 347,193 & 0,52967 & 0,5965 & 347,193 \\
Income & 0,1129 & 4,29455 & 0,0000 & 301,26 \\
Environmental Indicator & 4098,31 & 7,45368 & 0,0000 & 2796,11 \\
Education & 309,916 & 3,82202 & 0,0001 & 1480,88 \\
Dummy Variable & 5247,92 & 11,9362 & 0,0000 & 356,912 \\
Time local living & 15,046 & 1,97943 & 0,0481 & 293,45 \\
Gender & $-388,48$ & $-1,8117$ & 0,0704 & $-564,62$ \\
Family Size & 25,8792 & 0,45321 & 0,6505 & 106,189 \\
\hline
\end{tabular}

Total Economic Value of WTPASTA $\left(\mathbf{R} \$ \mathbf{h a}^{-1}\right)=\mathbf{5 . 0 1 1 , 1 9}$

WTPASTA Máx $\left(\mathbf{R} \$ \mathbf{h a}^{-\mathbf{1}}\right)=\mathbf{7 . 0 9 2 , 8 6}$

\begin{tabular}{lcccc}
\hline Variables & Coefficient & t-Statistics & Probability & $\begin{array}{c}\text { WTAASTA } \\
\text { Average }\end{array}$ \\
\hline Intercept & 5051,17 & 5,45963 & 0,0000 & 5051,17 \\
Income & 0,092 & 2,46897 & 0,0138 & 245,446 \\
Environmental indicator & 2270,97 & 2,83241 & 0,0047 & 1549,39 \\
Education & 216,988 & 1,85594 & 0,0638 & 1036,84 \\
Dummy Variable & 13103,3 & 31,0946 & 0,0000 & 1584,28 \\
Time local living & 9,0091 & 0,81564 & 0,415 & 175,709 \\
Gender & $-967,91$ & $-3,0864$ & 0,0021 & $-1406,8$ \\
Family Size & $-11,435$ & $-0,1414$ & 0,8876 & $-46,92$ \\
\hline
\end{tabular}

Total Economic Value of WTAASTA $\left(\mathbf{R} \$ \mathbf{h a}^{-1}\right)=\mathbf{7 . 3 6 7 , 2 4}$

WTAASTA Máx $\left(\mathbf{R} \$\right.$ ha $\left.^{-1}\right)=\mathbf{1 0 . 3 9 8 , 3 0}$

\begin{tabular}{lccc}
\hline Adjusted R-Square: WTPASTA & 0,558 & Mean of the dependent variable & 5117,38 \\
Adjusted R-Square: WTAASTA & 0,69206 & Mean of the dependent variable & 8189,15 \\
\hline
\end{tabular}

Source: Survey data. 
The income variable presented direct relation with WTPASTA and WTAASTA, indicating that people with higher income are willing to pay values above average for maintaining ASTAs, in order to preserve the welfare levels and improvements in environmental quality (Pearce; Turner, 1990; Biel et al. 2011; Costanza et al., 2014).

In this sense, an increase of $\mathrm{R} \$ 1.000,00$ in the interviewees' income tends to generate an increase in WTPASTA of R $\$ 112,90$ per hectare to preserve the rural properties with ASTA in Tomé-Açu, and an increase in WTAASTA of R $\$ 92,00$ per hectare to replace the ASTAs for another form of land use, ceteris paribus.

These results are consistent with those found in other studies, such as: Tostô (2010), which estimated the total economic value that the population of Araras is willing to pay for the revegetation of riparian forests; de Mattos et al. (2007), which estimated the value of permanent preservation areas of the Ribeirão São Bartolomeu watershed in the municipality of Viçosa; Adams et al. (2008), which used the contingent evaluation to estimate the total economic value of preserving the Morro do Diabo area in the Atlantic Forest; and in the research of Santana et al. (2016), which applied the IMCV to estimate the total economic value of the vegetation in the Metalófita Savannah area in the Carajás National Forest.

The education variable showed a positive result, indicating that the higher the level of education, the higher is the amount of willingness to pay for the preservation of the ASTAs areas of the municipality. Showing that, with each additional year of education there is an increase of R \$309,91 in WTPASTA per hectare, and of R \$216,99 in WTAASTA per hectare to replace this production system, ceteris paribus.

These results, underlying the impact of higher education more than income, demonstrate the importance of knowledge about ecosystem services and the benefits they generate for society. The result is linked to the teaching on environmental education in schools in the municipality, and the presence of universities that directly and indirectly contribute to environmental awareness and the maintenance of the cultural aspects and tradition of agroforestry practices used in the local production systems.

While to a smaller extent, when compared to this study, significant results attributed to the education variable were also reported in other works, to note: by Trujillo et al. (2016), in the studies of willingness to pay for the conservation of threatened coral reefs in the Caribbean; by Rosa et al. (2016), in the willingness to pay for the preservation of mangroves; by Santana et al. (2016), in the valuation of "canga"; and by Begot (2018), in the analysis of the externalities of a port project in the perception of fishermen.

In contrast, works that did not show statistical significance for the education variable can also be found, such as: Mattos et al. (2007), in the evaluation of the willingness to pay to conserve permanent preservation areas in the municipality of Viçosa; Tôsto (2010), in the estimation of the willingness to pay for revegetation of riparian forests; and Venerosi et al. (2014), in the willingness to pay for the reduction of ecological and health risks caused by floods in different climate scenarios.

The gender of the interviewee was shown as significant for specifying the model for both 
WTPASTA and WTAASTA. Since most interviewees are male, the results show that values are higher when the interviewee is male. This reflects the dominant Japanese culture in the research area, and that men follow the conduct of activities always in the perspective of socioeconomic and environmental sustainability and, therefore, are willing to value their activities.

According to Silva and Lima (2004), this behavior can occur due to the greater contribution of gender in family income and consequently in the spending decisions. In the case of Tomé-Açu, it may also be explained by the fact that most producers are male and are more involved in agricultural activities, which reflects the greater willingness to pay to preserve the ASTAs.

The variable "time living on the location" was significant for the WTPASTA equation, but not for the WTAASTA. The results indicate that for every additional year of living in the municipality, the average value of WTPASTA increases by $\mathrm{R} \$ 15,04 \mathrm{ha}^{-1}$, ceteris paribus.

The behavior of the variable may be linked to the effort to maintain the tradition of consortium plantations and the agricultural vocation of the municipality for cultivation in ASTAs. This eventually involves the resident population over time, given the temporary employment opportunities for women during the harvesting of black pepper, cocoa and various fruits.

The environmental indicator (environmental dimension) that captured the joint effect of 12 variables was highly significant. This variable, in addition to revealing the multifunctionality of the ASTAs in the perception of society, expresses the holistic character and intrinsic value of the natural assets.

It is worth noting that this indicator tends to highlight the degree of perception of interviewees about the socioeconomic and environmental benefits generated by the ASTAs in Tomé-Açu for the welfare and quality of life of local, regional and global society; integrating perceptions and behaviors related to the sustainability of natural assets with respect to its conservation for future generations (Quintero-Angel; González-Acevedo ,2018; Santana et al., 2018).

In this research, the increase of one unit in the average value of the environmental dimension indicator tends to increase WTPASTA and WTAASTA ceteris paribus by $\mathrm{R} \$ 4.098,30 \mathrm{ha}^{-1}$ and $\mathrm{R} \$ 2.270,97 \mathrm{ha}^{-1}$, respectively.

The environmental indicator reflects the participation of the environmental component in the total economic value of the ASTAs' natural assets. This knowledge integrates the factors of the environmental economy that admits the use of natural assets with the manufactured ones in non-fixed proportions, considering different degrees of substitution in the generation of other products and services, with factors used in the Ecological Economy analyses that admits the use of natural assets in relatively fixed proportions with the manufactured assets, admitting the substitutability among the assets only at the limit (Costanza et al. 1997; Santana et al., 2016; Santana et al., 2018).

Finally, the estimated average value of willingness to pay for the preservation of ASTAs in the Tomé-Açu (WTPASTA) was R $\$ 5.011,19 \mathrm{ha}^{-1}$; adding to this value the standard deviation gives a maximum value of $\mathrm{R} \$ 7.092,86 \mathrm{ha}^{-1}$. 


\section{Ml Macrothink}

For the willingness to accept (WTAASTA) to give up ASTAs areas for any other form of land use, an estimated average value of $\mathrm{R} \$ 7.367,24 \mathrm{ha}^{-1}$ was obtained, reaching a maximum value of $\mathrm{R} \$ 10.398,30 \mathrm{ha}^{-1}$ when adding the standard deviation. These values express only the value of ecosystem services provided by the ASTAs in the perception of society, and exceed in magnitude the market value of the Amazon rainforest and production systems, which revolve around $\mathrm{R} \$ 4.457,64 \mathrm{ha}^{-1}$ for livestock, $\mathrm{R} \$ 2.950,00 \mathrm{ha}^{-1}$ for family agriculture and $\mathrm{R} \$ 1.500,00 \mathrm{ha}^{-1}$ for the Amazon rainforest.

In the composition of the value of the ecosystem services of ASTAs' natural assets, the participation of the environmental dimensions was greater than the economic dimension (Figure 1).

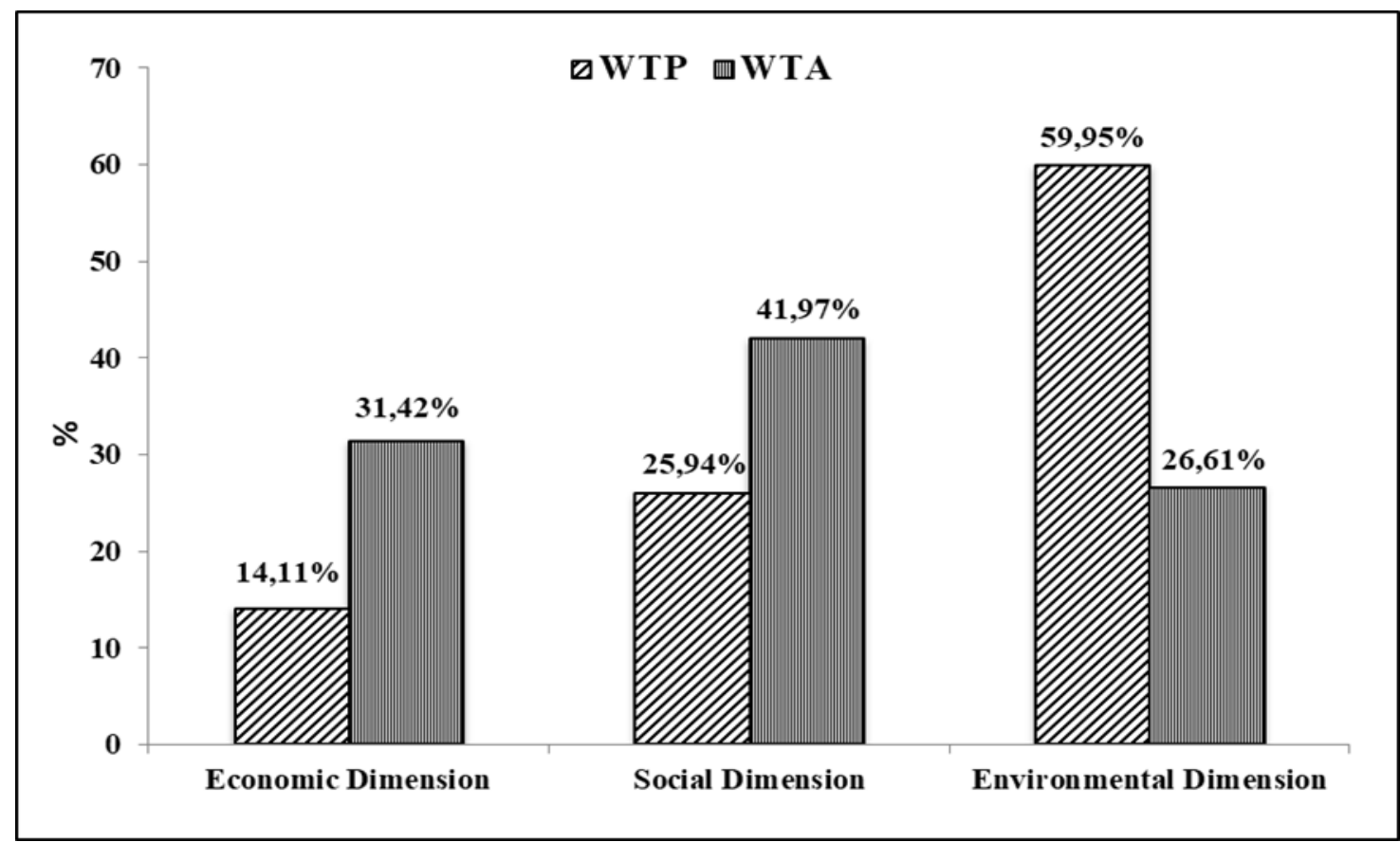

Figure 1. Composition of the total economic value of the ecosystem services of the natural asset of ASTAs

This aspect reflects how much society values the agroforestry systems in the region and strives for their conservation, perceiving them not only as an income-generating agricultural activity, but also as an important tool for ecological balance, maintenance of their levels of welfare and a fundamental part in the perpetuation of their history and culture, marked by the Japanese colonization (Daryanto et al., 2019).

\section{Conclusion}

The total economic value, estimated at an average of $\mathrm{R} \$ 5.011,19 \mathrm{ha}^{-1}$ for WTPASTA and $\mathrm{R} \$ 7.367,24 \mathrm{ha}^{-1}$ for WTAASTA was higher than the market value of the Amazon rainforest and production systems, which revolve around $\mathrm{R} \$ 4.457,64 \mathrm{ha}^{-1}$ for livestock, $\mathrm{R} \$ 2.950,00$ $\mathrm{ha}^{-1}$ for family agriculture and $\mathrm{R} \$ 1.500,00 \mathrm{ha}^{-1}$ for the forest. This highlighted the importance given by the population to the ecosystem services and benefits in welfare generated by ASTAs. 
From this perspective, a compensation policy for producers who have ASTAs in their rural properties becomes fundamental, given the range of ecosystem services generated and translated into the welfare of the population, not only local, but also regional and global. Thus, the value of the natural assets of the ASTAs instrumentalizes the implementation of public policies focused on the conservation of these assets and internalization of the value of ecosystem services generated by the ASTAs to rural properties.

This initiative in strengthening of agroforestry practices, together with the integration of payment to compensate rural producers that maintain these systems in the Amazon, tends to generate a trajectory of sustainable development in the region.

\section{References}

Adams, C., Seroa, R., Arigoni, R., Reid, J., Aznar, C. E., Antonio, P., \& Sinisgalli, D. A. (2007). The use of contingent valuation for evaluating protected areas in the developing world: Economic valuation of Morro do Diabo State Park, Atlantic Rainforest, São Paulo State (Brazil). 6. https://doi.org/10.1016/j.ecolecon.2007.09.008

Baral, N., Stern, M. J., \& Bhattarai, R. (2008). Contingent valuation of ecotourism in Annapurna conservation area, Nepal: Implications for sustainable park finance and local development. 6. https://doi.org/10.1016/j.ecolecon.2008.02.004

Barros, A. V. L. De, Homma, A. K. O., Takamatsu, J. A., Takamatsu, T., \& Konagano, M. (2009). Evolução e percepção dos sistemas agroflorestais desenvolvidos pelos agricultores nipo-brasileiros do município de Tomé-açu, estado do Pará *. Amazonia: Ciência \& Desenvolvimento, 5(9), 121-152.

Begot, L. H. (2018). Valoração e sustentabilidade da pesca artesanal de Curuça e Colares, Estado do Pará: uma análise das externalidades de um projeto portuário na percepção dos pescadores. (Unpublished doctoral dissertation) - Federal University of Pará. Belém.

Bentes, E. dos S., Santana, A. C. de, Homma, A. K. O., \& Gomes, S. de C. (2015). Valoração econômica da jusante da barragem de Tucuruí. Revista de Política Agrícola, 23(4), 102-110. https://seer.sede.embrapa.br/index.php/RPA/article/view/957

Biel, A., Johansson-Stenman, O., \& Nilsson, A. (2011). The willingness to pay-willingness to accept gap revisited: The role of emotions and moral satisfaction. Journal of Economic Psychology, 32(6), 908-917. https://doi.org/10.1016/j.joep.2011.07.010

Bishop, R. C., \& Romano, D. (Ed). (1998). Environmental resource valuation: applications of the contigent valuation method in Italy Boston: Kluwer Academic Publisher, 11(1), 286. https://doi.org/10.1007 / 978-1-4615-5741-8

Carson, R. T. (2012). Contingent valuation: A practical alternative when prices aren't available. Journal of Economic Perspectives, 26(4), 27-42. https://doi.org/10.1257/jep.26.4.27

Costanza, R., D’Arge, R., De Groot, R., Farber, S., Grasso, M., Hannon, B., ... Van Den Belt, M. (1997). The value of the world's ecosystem services and natural capital. Nature, 387(6630), 253-260. https://doi.org/10.1038/387253a0 
Costanza, R., de Groot, R., Braat, L., Kubiszewski, I., Fioramonti, L., Sutton, P., Farber, S., \& Grasso, M. (2017). Twenty years of ecosystem services: How far have we come and how far do we still need to go? Ecosystem Services, 28, 1-16. https://doi.org/10.1016/j.ecoser.2017.09.008

Daryanto, S., Jacinthe, P. A., Fu, B., Zhao, W., \& Wang, L. (2019). Valuing the ecosystem services of cover crops: barriers and pathways forward. Agriculture, Ecosystems and Environment, 270-271(October 2018), 76-78. https://doi.org/10.1016/j.agee.2018.10.021

Farber, S. C., Costanza, R., \& Wilson, M. A. (2002). Economic and ecological concepts for valuing ecosystem services. Ecological Economics, 41(3), 375-392. https://doi.org/10.1016/S0921-8009(02)00088-5

Groot, R., Brander, L., van der Ploeg, S., Costanza, R., Bernard, F., Braat, L., ... van Beukering, P. (2012). Global estimates of the value of ecosystems and their services in monetary units. Ecosystem Services, 1(1), 50-61. https://doi.org/10.1016/j.ecoser.2012.07.005

Instituto Brasileiro de Geografia e Estatística (IBGE) (2019). Cidades: Tomé-Açu. Brasília: IBGE, 2019. Retrieved from: https://cidades.ibge.gov.br/brasil/pa/tome-acu/panorama

Liu, S., Costanza, R., Farber, S., \& Troy, A. (2010). Valuing ecosystem services: theory, practice, and the need for a transdisciplinary synthesis. Annals of the New York Academy of Sciences, 1185, 54-78. https://doi.org/10.1111/j.1749-6632.2009.05167.x

Marshall, A. (1992). Princípios de economia. São Paulo: Abril Cultural, 272p.

Mattos, Ana Dantas Mendez de, Jacovine, Laércio Antônio Gonçalves, Valverde, Sebastião Renato, Souza, Agostinho Lopes de, Silva, Márcio Lopes da, \& Lima, João Estáquio de. (2007). Valoração ambiental de áreas de preservação permanente da microbacia do ribeirão São Bartolomeu no Município de Viçosa, MG. Revista Árvore, 31(2), 347-353. https://doi.org/10.1590/S0100-67622007000200018

Millennium Ecosystem Assessment (MEA). (2003). Ecossistemas e bem-estar humano: Estrutura para uma avaliação [Sl]: Millennium Ecosystem Assessment (MEA). Retrieved from: https://wwwmillenniumassessmentorg/document63aspxpdf

Pearce, D. W., \& Turner, R. K. (1990). Economics of natural resources and the environment London: Harvester Wheat sheaf. 378p.

Quintero-Angel, M., \& González-Acevedo, A. (2018). Tendencies and challenges for the assessment of agricultural sustainability. Agriculture, Ecosystems and Environment, 254(April 2017), 273-281. https://doi.org/10.1016/j.agee.2017.11.030

Rosa, A. G., Santana, A. C., Oliveira, C. M., \& Santana, Á. L. (2016). Valoração contingente da reserva extrativista de marinha Caeté-Taperaçu, Bragança, estado do Pará - Brasil Espacios (Caracas), 37(9), 1-13.

Santana, A. C. de, Santana, Á. L. de, Oliveira, G. M. T. S., Santana, Á. L. de, \& Quaresma, J. L. (2018). A importância dos serviços ecossistêmicos para o desenvolvimento econômico e o bem-estar social na percepção da população: O caso da floresta nacional de Carajás. Nativa, 6 , 689. https://doi.org/10.31413/nativa.v6i0.6418

Santana, A. C. De, Santana, A. L. De, Santana, A. L. De, Gomes, S. C., \& Salomão, R. De P. (2015). Valoração dos danos ambientais causados por hidrelétricas para a produção de energia 
na bacia do Tapajós. Reflexões Econômicas, 1(1), 31-48.

Santana, A. C., Salomão, R. P., De Santana, Á. L., Castilho, A. F., \& Gomes, S. C. (2017). O valor econômico da savana metalófita da Floresta Nacional de Carajás, estado do Pará: uma contribuição teórica e metodológica. Revista Teoria e Evidência Econômica, 23(48), 9-38. https://doi.org/10.5335/rtee.v23i48.7358

Santana, A. C. (2018). Os ativos naturais de imóveis rurais na Amazônia, acesso a crédito e capitalização do produtor. Inclusão Social, 12(1), 58-72.

Santana, A. C. (2015). Valoração de produtos florestais não-madeireiros da Amazônia: o caso da Castanha-do-Brasil. (Full professor thesis) - Federal Rural University of the Amazon. Belém.

Santana, A. C., \& Khan, A. S. (1992). Custo social da depredação florestal no Pará: o caso da castanha-do-brasil. Revista de Economia e Sociologia Rural. 30(1). 253-269.

Santana, A. C., Santana, Á. L., Amin, M. M., Salomão, R. P., Costa, N. L., Santos, M. A. S., \& Castilho, A. F. (2017). Theoretical and methodological contributions to the contingent evaluation of the natural resources of the Carajás National Forest. International Journal of Development Research, 7(4), 12468-12474.

Silva, Rubicleis Gomes da, \& Lima, João Eustáquio de. (2004). Valoração contingente do Parque "Chico Mendes": uma aplicação probabilística do método Referendum com bidding games. Revista de Economia e Sociologia Rural, 42(4), 685-708. https://doi.org/10.1590/S0103-20032004000400008

Tôsto, S. G. (2010). Sustentabilidade e valoração de serviços ecossistêmicos no espaço rural do município de Araras, SP. (Unpublished doctoral dissertation) - State University of Campinas, São Paulo.

Trujillo, J. C., Carrilo, B., Charris, C. A., \& Velilla, R. A. (2016). Coral reefs under threat in a Caribbean marine protected area: Assessing divers' willingness to pay toward conservation Marine Policy, 68(1), 146-154. https://doi.org/10.1016/j.marpol.2016.03.003

Veronesi, M., Chawla, F., Maurer, M., Lienert, J. (2014). Climate change and the willingness to pay to reduce ecological and health risks from wastewater flooding in urban centers and the environment. Ecological Economics, 98(1), 1-10. https://doi.org/10.1016/j.ecolecon.2013.12.005

Wallace, K. J. (2007). Classification of ecosystem services: problems and solutions. Biological Conservation, 139(4), 235-246. https://doi.org/10.1016/j.biocon.2007.07.015

\section{Copyright Disclaimer}

Copyright for this article is retained by the author(s), with first publication rights granted to the journal.

This is an open-access article distributed under the terms and conditions of the Creative Commons Attribution license (http://creativecommons.org/licenses/by/4.0/). 